\section{Accounting, management and accountability in times of crisis: lessons from the COVID-19 pandemic}

Accounting and management in times of crisis

\author{
Giulia Leoni
}

Department of Economics and Management Studies, University of Genoa, Genoa, Italy

Alessandro Lai and Riccardo Stacchezzini

Department of Business Administration, University of Verona, Verona, Italy

Ileana Steccolini

Essex Business School, University of Essex, Colchester, UK

Stephen Brammer

School of Management, University of Bath, Bath, UK

Martina Linnenluecke

Center for Corporate Sustainability and Environmental Finance,

Macquarie University, Sydney, Australia, and

Istemi Demirag

Department of Business Administration, Tallinn University of Technology,

Tallinn, Estonia

\begin{abstract}
Purpose - The purpose of this paper is to discuss the themes emerging from the first studies exploring accounting, accountability and management practices during the COVID-19 pandemic and coming from a diversity of experiences, across countries, organizations and individuals. In so doing, the paper gives an overview of the most recent findings about the role of accounting and accountability in times of crisis that are hosted in this special issue of Accounting, Auditing and Accountability Journal (AAAJ).

Design/methodology/approach - The paper draws together and identifies emerging themes related to the current COVID-19 pandemic and its impacts on accounting, accountability and management practices and considers how the studies in this issue extend one's knowledge of accounting and contribute to accounting research. Findings - Three emerging themes are drawn and their contribution to accounting scholarship is discussed. The first theme deals with the role of accounting and numbers in supporting governmental responses to
\end{abstract}

(C) Giulia Leoni, Alessandro Lai, Riccardo Stacchezzini, Ileana Steccolini, Stephen Brammer, Martina Linnenluecke and Istemi Demirag. Published by Emerald Publishing Limited. This article is published under the Creative Commons Attribution (CC BY 4.0) licence. Anyone may reproduce, distribute, translate and create derivative works of this article (for both commercial and non-commercial purposes), subject to full attribution to the original publication and authors. The full terms of this licence may be seen at http://creativecommons.org/licences/by/4.0/legalcode

The authors are very grateful to the authors who contributed to this special issue and the dedicated referees who made enormous efforts in helping with paper reviews. Also, the authors appreciated the reviews of our introduction. The authors are also particularly thankful to Professor James Guthrie, who provided strong support and valuable suggestions to manage this AAAJ special issue successfully. Any remaining errors are the authors' own responsibility.

Funding: This research received no specific grant from any funding agency in the public, commercial, or not-for-profit sectors.

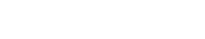


AAAJ 34,6

1306

COVID-19. The second theme considers accounting practices used to make exceptional decisions at the organizational level in times of crisis. The third theme addresses a relevant frontier of research into accounting and inequalities.

Practical implications - In considering the diverse contributions of this special issue, the paper points out how uncertainty and change can impact the design, use and understanding of accounting, management and accountability practices and can be accepted by scholars and practitioners as part of such practices.

Originality/value - This paper provides a timely and comprehensive picture of the first reflections and research findings on the impacts of the COVID-19 pandemic on one's interpretation of accounting, accountability and management practices.

Keywords COVID-19, Emergency, Crisis, Accounting, Accountability, Management

Paper type Research paper

\section{Introduction}

The Global Preparedness Monitoring Board (GPMB) (2019) warned in September 2019 that the world was at risk from deadly pandemics and governments should prepare for - and mitigate - the effects of a widespread global health emergency that could kill millions and damage the global economy. This report echoes the many prior warnings in scientific publications of the inevitability of the next pandemic (e.g. Murray et al., 2006), especially in the aftermath of the severe acute respiratory syndrome (SARS) and the Influenza A (H1N1) outbreaks in 2003 and 2009, respectively. Despite the increasingly dire risk of widespread epidemics, the world remained unprepared. The GPMB (2019) highlights that epidemic-prone diseases such as Ebola, influenza and SARS are frequently challenging to manage in the face of prolonged conflicts, fragile states and forced migration. At the same time, the threat of a pandemic spreading around the globe is a real one. In essence, a quick-moving pathogen has the potential to kill millions of people, disrupt economies and destabilize national security. Climate change, urbanization, air travel and a lack of adequate water and sanitation are all breeding grounds for fast-spreading, catastrophic diseases.

With the outbreak of the COVID-19 pandemic (Coronavirus) in December 2019 in China, humanity faced an emergency that primarily concerned health and safety. At the same time, the extreme measures to slow down deaths and contaminations are having a significant impact on individuals' lives, public policies, society as a whole and the economy, in countries worldwide. Eighteen months later, the COVID-19 virus has infected 156 million people and caused the death of 3.25 million people worldwide [1]. Since the beginning of the pandemic, the timescale of the current global health crisis linked to the Coronavirus COVID 19 remains uncertain. While since January 2021, a global vaccination campaign has started, the fallout from the pandemic has been and is still dire, both socially and economically, including related deaths, job losses and company bankruptcies, public sector debt, broken supply chains and mental health issues related to lockdown policies amongst others (Brammer et al., 2020). The disproportionate impacts of the current crisis on already disadvantaged groups (low-income workers, those in casual/ temporary/precarious employment, females, non-whites, migrants and older populations) have significantly deepened both intra- and inter-country social and economic inequalities.

The disruptive force of this health and global emergency has clearly demonstrated that the goals established to overcome the crisis are superordinate goals that are largely mute with respect to social, ecological and financial intentions. This crisis has disproportionately affected some of the most vulnerable people on Earth. For instance, the fight against poverty - which is included in the United Nations Sustainable Development Goals (UNSDGs) - has reversed by around three years due to the COVID-19 emergency. The World Bank has estimated that if in $20179.2 \%$ of the world population (689 million people) was living in extreme poverty, the COVID-19 crisis has pushed between 88 and 115 million people into extreme poverty, delaying the results of the fight against poverty by around three years [2]. As a consequence, will the current UNSDGs need to be reviewed, or will the crisis spur a superordinate effort towards achieving them (Bebbington and Unerman, 2018)? Is this crisis helping humanity to learn new 
lessons about how to tackle these global issues or has it simply worsened an already bad situation? Where do we go from here? How are accounting, accountability and management practices supporting (or hindering) the search of solutions to these wicked problems?

This pandemic has shown to the world that this unprecedented crisis requires even more interdisciplinary and cross-country collaboration of all members and institutions of society to overcome the emergency and the health, economic, social and environmental implications, both immediate and long-term. As a response, academics in every discipline have started to investigate the impacts of this global health emergency in an attempt to provide new solutions and new ways.

As accounting and management scholars, we believe that there is an urgent need for new studies addressing the implications of large-scale global crises for individuals, organizations and society, which had still remained mostly unexamined in accounting and management research. Contributions do exist on the role played by accounting in the global financial crisis that began in 2008 (e.g. Barbera et al., 2020; Al Mahameed et al., 2020; Bracci et al., 2015; Chabrak and Gendron, 2015; Hodges and Lapsley, 2016). Extant research has investigated the impacts of extreme events on organizations and their decision-making (Wilson et al., 2010) and the resilience of organizations in the context of specific crises or extreme events (Rouleau et al., 2021; Linnenluecke, 2017; Barbera et al., 2017). Recent research in accounting has extended its focus on the role of accounting in the context of natural disasters, accidents or risks that affect individuals, organizations and industries (Sargiacomo, 2014; Lai et al., 2014; Sargiacomo et al., 2014; Sargiacomo, 2015; Perkiss and Moerman, 2017; Matilal and Adhikari, 2019).

However, what is evident from this research is that organizations, businesses, governments and communities are mostly unprepared to deal with significant large-scale disruptions and their responses are reactive and adaptive, rather than anticipatory or transformational. Research across various disciplines, including accounting, management and public administration has increasingly emphasized the need to respond to "grand challenges" and "wicked problems" such as climate change, socio-political uncertainty, poverty alleviation and global health improvement (Thomasson et al., 2020; Brammer et al., 2019; Head, 2019; Steccolini, 2019; Jacobs and Cuganesan, 2014). For instance, Dumay et al. (2020) state that to make a significant contribution to society, our research community will need to address severe and fundamental global problems and contribute to learning the lessons from this pandemic, thereby disputing the "belief that markets can act as an appropriate proxy for the common good.” (Dumay et al., p. 8). Such studies may contribute to the evolution of the use of accounting systems by governments and public sector institutions that can be used to shape "how crises and austerity are perceived, interpreted and tackled, providing organizations with the relevant capacities, tools and resources to anticipate and cope with unexpected events.” (Steccolini, 2019).

In response to this, we called for multi-disciplinary contributions from accounting and management academics worldwide to explore accounting, accountability and management practices during the pandemic, discuss pressing global challenges and envision possible future solutions based on the lessons learned from this crisis.

\section{Accounting and COVID-19 special issue: emerging themes}

With this special issue we aimed to reveal the role played by accounting, accountability and management practices in the COVID-19 pandemic at a global level to extend our knowledge of accounting, accountability and management in times of emergency and to reflect on the lessons to be learned to improve the preparedness of organizations and society and prevent future crises. As previously found during the global financial crisis and in natural disasters, we expected that also in this severe global crisis, accounting, management and accountability 
AAAJ 34,6

1308 practices may play a multifaceted role in governmental and non-governmental organizations' decision-making and policies; in public services, businesses and not-for-profit organizations responding to the crisis; as well as with respect to the state of the human condition.

Taking the form of a global crisis, the pandemic affected the whole society at all levels, thereby calling for emergency responses and support at all levels, such as individuals, businesses of any size, for-profit and not-for-profit sector, public sector, governments and public institutions. This provides a unique opportunity to understand and experience the full extent of the potential of accounting and management systems and practices, as these will be used to justify tough decisions, to engage citizens and stakeholders, to provide information in emergency situations, to provide exceptional forms of accountability and communication, to discipline people and behaviours in new ways, but also to potentially offer opportunities of empowerment.

On this basis, we were confident that this special issue was necessary and timely and would attract insightful contributions. Indeed, the response from the accounting and management academic community was unprecedented. We received 175 submissions from 33 different countries and with a large variety of themes, investigated contexts, organizational perspectives, as well as theoretical and practical insights. We are proud to introduce this first special issue that collects 14 contributions providing different and insightful evidence on the role of accounting, management and accountability in COVID-19 times. These selected investigations are very diverse with respect to their investigated contexts, their theoretical approaches and their study objects, but they all offer reflections on the role of accounting and accountability systems during the current pandemic and provide lessons for the future of society and organizations.

While diverse in their contents, the papers can be grouped into three categories, each one representing an emerging theme related to accounting, accountability and management in times of emergency. A first group of four contributions deals with the role of accounting for exceptional decision-making at the government and country level, exploring the ways in which governments used numbers, calculative practices and big data in governing (or trying to govern) the pandemic (Mitchell et al., 2021; Ahrens and Ferry, 2021; Ahmad et al., 2021; Ahn and Wickramasinghe, 2021). A second group of seven contributions addresses the roles of accounting and accountability in exceptional decision-making at the organizational level, focussing on a variety of organizations, including businesses, not-for-profit organizations and charities (Carungu et al., 2021; Velayutham et al., 2021; Delfino and van der Kolk, 2021; Passetti et al., 2021; Sargiacomo et al., 2021; Kober and Thamber, 2021; Huber et al., 2021). Finally, the last three contributions point to the role of accounting in perpetuating inequalities in the context of the pandemic, with a focus on how traditional accounting practices may exacerbate inequality in society (Andrew et al., 2021; Christ and Burritt, 2021; Nikidehaghani and Cortese, 2021).

\section{The role of accounting and numbers in supporting government responses to the pandemic: a country and policy perspective}

Four papers in the special issue specifically took a country-level perspective, exploring the ways in which governments used numbers, calculative practices and big data in governing (or trying to govern) the pandemic. This cluster of studies points out how accounting and calculative practices, ranging from budgets, performance reports, data on tests and biometric data on citizens, played a relevant role in enabling governments to "keep the pandemic under control", whilst at times generating dangerous drawbacks in terms of personal freedom and protests.

Mitchell et al. (2021) adopt a pragmatic constructivist lens to look at how performance management practices in Germany, Italy and the United Kingdom have shaped different country responses to the pandemic. The planning, anticipation, lockdown and loosening up of 
lockdown phases provide the setting for the authors to contrast the four dimensions of facts, possibilities, values and communication across countries. The authors find that these dimensions allow them to explain the different behaviours and relative "success" of countries in facing the pandemic. Interestingly, in Germany, singularity of values was conducive to better goal clarity, and a focus on the acquisition of factual information enabled evidencebased generation of action possibilities. This also allowed prompt recognition of the severity of issues. Strong learning and communication, with the involvement of scientists, politicians and the public, supported the country's relative success against the pandemic. Conversely, according to the authors, in the other two countries, governments were slower to act and respond, probably as a reflection of a more pronounced plurality of values, which made a decisive response more difficult. Only the severity of the problem forced decisions and stronger reliance on factual data, reflecting an overall lack of integration of the elements of the framework.

A closer look at the UK responses to the pandemic is offered by two other contributions in this special issue. Ahrens and Ferry's (2021) paper draws on Foucault's concept of "apparatuses of Security" to explore UK government's uses of accounting and accountability in its response to COVID-19. In doing so, the paper shows that the UK government governed the COVID-19 pandemic through accounting, economic and statistical calculative practices (including those in epidemiology and healthcare), having to balance multiple pressures and priorities. As such, the government had to face the uncertainty of a growing debt, coupled with larger than expected budget deficits due to reduced revenues and increased emergency expenditure. The authors highlight that accounting has the potential to enable the government to appreciate the extent of a crisis and produce calculations to support responses to it. However, they also claim that the government only relied on a few of the available accounting tools (such as monthly statistical reporting and budgeting flexibilities), not reaping all the possible benefits of using in a timely manner the spending review and accountability tools potentially available. They thus suggest that in the future, accountability should cover both the financial value for money and fairness aspects so that citizens as subjects remain supportive of government action.

Ahmad et al. (2021) offer a complementary analysis of the UK responses to the pandemic and show how testing played both an inscription and classificatory role in the COVID-19 pandemic context. In particular, the authors find that testing initially played an inscription role, in response to political needs and considerations, more than being driven by scientific recommendations, thus undermining their reliability and effectiveness in responding to the disease. However, subsequently, testing strengthened its classificatory role, with the development of the country diagnostic infrastructure, which allowed a better response to the pandemic, guiding government plans through the identification of risk categories. As such, the authors suggest that testing allowed the UK government to manage actors and thus the pandemic at "multiple distances". Interestingly, and similar to Ahrens and Ferry (2021), the authors also point out that the COVID-19 pandemic has increasingly highlighted that in a future possible "new normality" it will be difficult to continue conceiving of governing populations focussing on fiscal goals and austerity measures, as the demand for public health services will be likely to be increasing rather than diminishing.

Ahn and Wickremasinghe's (2021) study, similar to previous papers, looks at the societal implications of calculative practices, but with a focus on the use of big data in South Korea. They show how the pandemic provided the context for a surveillance assemblage to be put in place to control and hold citizens accountable. This was made possible by a convergence of "desires", whereby the government desired to enhance its legitimacy and approval rate by controlling the pandemic, and the citizens desired to maintain their health and safety. At the same time, this invaded the territory of individual privacy, as citizens were held accountable to the surveillance assemblage for their locations and health conditions. 
AAAJ 34,6

1310
This cluster of studies highlights that accounting and calculative practices, ranging from budgets, performance reports, data on tests and biometric data on citizens, played a fundamental role in enabling governments to "keep the pandemic under control". However, they also point to possible critical issues and drawbacks. These may include the difficulties arising when the alignment between facts, values, possibilities and communication is limited (as pointed out by Mitchell et al., 2021); the risks related to a reductionist focus and prioritization of only certain dimensions, measures and certain values (such as economy or fiscal balance as opposed to health; or overall control over health and population as opposed to individual privacy); and the specific risks emerging when digital technologies allow the collection of individual data and present the potential to exercise full surveillance on their lives with the excuse of the exceptionality of circumstances.

As such, the studies highlight that accounting may still risk being conceived as a disciplining and decision tool, focussing mostly on financial issues and the need to balance budgets (Bracci et al., 2015). They however show clearly that this reductionist approach to accounting and calculations on the one hand does not allow consideration of the plurality of priorities and needs which governments need to face and satisfy. On the other hand, it does reflect the potential that accounting has to increase the visibility of and be at the intersection among alternative values and needs, such as fairness, social equity, global, national and individual health.

Current studies also highlight that there is a need to better understand whether the new surveillance regimes, budgetary and accountability practices which have become legitimated and accepted under the pandemic will remain in the "new normal" or rather will be replaced by new emergent calculative and accountability practices. More generally, they all point to the importance of not taking for granted the underlying "values" governing calculative and accounting practices, as the pandemic has shown that they may shift both gradually and suddenly, and become contested, requiring mediation, compromise or giving rise to conflicts and contradictions. After many years of accounting research being dominated by studies on neo-liberalism and "economization" processes, it will be thus interesting to see how the "new normal" post-COVID-19 will continue to perpetuate neo-liberal models or rather witness the rise of alternative ones, and how this will shape and be shaped by calculative practices. In particular, it will be interesting to see if in the new post COVID-19 world accounting will be reinterpreted to offer a richer and more comprehensive perspective on what is "valued" and "measured" (e.g. fiscal goals or fairness and social equity? Surveillance or privacy? Economy or Health? Climate change or economic wealth?) and how it will mediate among plural, different values.

\section{Accounting for exceptional decision-making at the organizational level}

Accounting research has only recently started to deal with natural disasters and humanitarian crises (Capelo and Araújo, 2019; Lai et al., 2014; Leider et al., 2017; Sargiacomo et al., 2014; Sargiacomo, 2015) as well as financial crises (Bracci et al., 2015; Barbera et al., 2017, 2020) trying to determine the role of accounting in such circumstances from a critical and interpretive perspective (Sargiacomo, 2014), the way in which accountability could enhance a common trust towards the recovery actions (Sciulli, 2018), as well as the support of auditing in monitoring recovery processes. However, these studies deal with natural or humanitarian disasters in very limited and specific areas of the world (Matilal and Adhikari, 2019). Before the outbreak of COVID-19, we had to go back to World Wars I and II of the last century or to the Spanish flu outbreak at the beginning of the 20th century to contemplate a natural or humanitarian disaster on a global scale. Thus, the current COVID-19 crisis has highlighted the scarcity of knowledge on the role of accounting and management practices in a global emergency, where lives and human activities are put at risk 
all around the world. The global scale of the COVID-19 pandemic is inevitably impacting all types of organizations, such as private and public sector institutions, businesses, nongovernmental organizations and not-for profit organizations. As a result, seven contributions of this special issue provide insights into the role of accounting and accountability in supporting (or hindering) exceptional decision-making in various types of organizations facing the current global health emergency, as well as how people and organizations have reacted to in this unprecedented situation.

In an attempt to reveal accountants' behaviour in situations departing from normal ones, Carungu et al. (2021) provide an interpretive perspective based on action research. Via semistructured interviews and active participation of an author in a professional organization, the authors demonstrate that the pandemic generates relevant changes in the accountants' experience: some are short-term effects, while others will be better appreciated from a longterm perspective. By implementing a combined range of contingent reactions, accountants are found to be able to immediately minimize the effect of the pandemic, interpreting accounting as a "key facilitating technology"; the contingent shock also brings about an adaptive approach of the new work routines and organization, revealing the learning abilities of organizations and their members to rely on accounting practices to re-create a new normality in the organization. The paper contributes to the literature on disasters (Lai et al., 2014), considering both short-term and long-term effects on accountants and confirms nine contingent phases (Walker, 2014) to respond to emergency situations.

Similarly, also Delfino and van der Kolk (2021) investigate the impacts of a sudden shift from a normal work environment to remote working in professional service firms and their employees. However, they focus on the changes in management control practices during the first phases of the COVID-19 pandemic. The analysis is based on interviews with 15 employees working in different professional service firms located in Italy. With the shift to remote working, management control practices transitioned to online meetings and leveraged digital technologies to monitor employees at a distance. For their part, employees worked to make their efforts visible to the superiors, with increased levels of stress, reduction in their autonomy and changes in their perceptions of hierarchies and their sense of trust and affinity. Thereby, remote digital control and calculative practices generated a negative perception of management control systems in COVID-19 times. The paper contributes to the literature on management control practices and employee motivation and calls for further research on its side effects.

Management control systems as implemented by a cooperative are the study object of Passetti et al. (2021), who explore the role(s) of management control systems in supporting organizational decision-making during the lockdown period of the COVID-19 pandemic. Based on the case study of an Italian large food retail cooperative, the research benefits from video-recorded semi-structured interviews to organizational members of this cooperative. The interpretation of the evidence collected is informed by the object-of-control framework (Merchant and Van der Stede, 2012) and relies on the distinction between organic and mechanistic management controls (Chenhall, 2003). The analysis reveals that management control mechanisms play a critical role in supporting organizational response to the crisis, because they facilitate internal coordination, help redefine operational practices and give visibility to objectives and results. They also facilitate collaboration with local communities and offer opportunities to mitigate the inequalities generated by the pandemic. As such, the scholars argue that management controls played a technical, facilitating and even moral and emotional role during the initial phase of the pandemic.

Differently, accounting as a control and monitoring tool was found to be missing (and greatly needed) in supply chains during the pandemic. The current pandemic and the halt to many business activities have also affected organizations' supply chains, as investigated by Velayutham et al. (2021) in the case study of Fisher and Paykel Healthcare, a New Zealand 
AAAJ 34,6

1312

company specializing in respiratory systems. The research reveals the increasing uncertainty faced by the company due to the lack of supply of raw materials and the labour-intensive manufacturing as a result of COVID-19 and related restrictions. By showing how the pandemic disrupted both markets, logistics and customer demands, the paper demonstrates that such disruption was worsened by the lack of dissemination of appropriate accounting information along the supply chain (SC) up to the managers. Through the casestudy analysis, the authors provide indications regarding four instances when an accounting system can improve the performance of supply chains: (1) management accountability and identification of risks and uncertainties and the associated impact, (2) the use of accountingintegrated SC systems in short-term and long-term planning, (3) the communication of the financial impact of SC disruptions on shareholder value and debt repayments and (4) the uses of accounting information as a mechanism for external financing of the SC.

Focussing on a network of public and private sector organizations collaborating together to assist vulnerable people of the city of Turin (Italy), Sargiacomo et al. (2021) explore the accounting, accountability and calculative practices activated by this network committed to provide food and assistance to indigent people during the food emergency caused by the COVID-19 pandemic. The paper is informed by the Foucauldian concept of governmentality (Foucault, 1991) and benefits from documental analysis and interviews with institutional actors of the organizations involved. The analysis reveals the extensive use of accounting and calculative practices as technologies of government, at national, local and organizational levels. However, in line with the concept of governmentality, accounting tools used to count people needing food assistance remain an incomplete practice, thus requiring new classification systems and related organizational solutions, thereby illustrating how existing accounting systems can be less pertinent in times of exceptional times.

As clearly depicted by Kober and Thamber (2021), charities have been greatly affected by the pandemic, especially in terms of lack of financial means to operate. Kober and Thamber (2021) explore the role of accounting in shaping a charity's financial resilience during the COVID-19 crisis. This involves an attempt to understand the charity's capacity to cope with the financial impacts of the crisis (Barbera et al., 2020) and shows how the calculative practices have enabled sense shaping, based on accounting calculations in terms of boxes of supply, with their financial implications. This analysis has some relevance to the prior research theme on the role of accounting in crisis (Boin et al., 2016; Newberry, 2020; Sargiacomo, 2015) and complements it by highlighting how a sense shaping process is carried out in a charity organization by senior and operational managers sharing their knowledge and expertise through planning meetings and by developing calculative practices in order to resolve financial issues in exceptional times.

Inevitably, public health institutions, such as hospitals and clinics, are centre stage in the fight against the virus (Demirag et al., 2021). Huber et al. (2021) examine the role of accounting in the management of the COVID-19 pandemic in five German hospitals. Via an ethnographic analysis, the authors collect their data through three rounds of interviews, ethnographic observations of meetings and document analysis in five German hospitals, between February and August 2020. They articulate how actors established an "accounting infrastructure" around several indicators, such as swab tests, testing kits, ventilators and the number of intensive care beds for COVID-19 patients in the pandemic. They found that the intensive care beds are assumed as central indicators for decision-making in the hospitals. The study finds that the COVID-19 pandemic has resulted in different relations between organizations and field level and provides a valuable contribution to the role of accounting in crisis literature, although this change of emphasis on accounting is not unusual.

While each of the seven papers offers a stimulating investigation about the impacts of the pandemic on various organizations' decision-making process, it is possible to draw further insights that can contribute to the interdisciplinary accounting literature. First, all the papers 
enrich the literature on accounting and disasters by including global-scale emergencies, widening the types of organization affected and the way they differently face a crisis. Secondly, the papers reveal the different roles and perceptions of accounting and calculative practices under extreme circumstances. For instance, accounting is found to be a useful tool to respond to the immediate uncertainty posed by the outbreak of the pandemic (Carungu et al., 2021; Passetti et al., 2021; Sargiacomo et al., 2021), although some accounting and accountability systems are found not to be well received within the organization (Delfino and van der Kolk, 2021). Moreover, the papers highlight differences in the perception and use of accounting as a tool for control at a distance and for coordination. Indeed, while the presence of an accounting system was vital for the City of Turin in the coordination of a network of organizations (Sargiacomo et al., 2021), the lack of it in the analysed case of New Zealand SC made impossible to control the shortages generated by the pandemic (Velayutham et al., 2021). Also, accounting proved a useful tool for charitable organizations and may continue to be used in the future, as it may help them to assess their financial distress and improve their financial resilience (Kober and Thamber, 2021). Finally, as accounting is found to have different impacts among similar organizations (i.e. networks), these papers also reveal the paramount importance of understanding the cultural characteristics of the contexts in which these organizations are embedded, as these can contribute to the success or failure of accounting and accountability practices.

The above emerging trends from current research on accounting in exceptional times are organizational and culturally specific: generalizations are therefore difficult to make. However, some common issues on the role of accounting in the operations of public and private organizations remain, and these must be addressed. Given that the changes in crisis operations and the relating accounting have been rapid in organizations, scholars and policymakers will need to decide what aspects of these changes must be kept in the future and how this change will impact on other control mechanisms and performance. What lessons can be learned from the crisis by internal and external auditing teams as well as regulators? To answer these significant questions, more case studies to increase the potential learning capacity of organizations to deal with crisis will be needed, by systematically facilitating interorganizational learning through mirroring authors' insights back to the actors and preparing executive summaries at the operational levels. Future research should also consider the differences in different accountability contexts, cultures and under different organizational funding and governance systems.

\section{Accounting and inequalities}

Accounting is not a socially neutral activity (Bryer, 2014). The calculative, auditing, assurance and transparency aspects of accounting have the potential to encourage significant organizational and wider societal change (Catchpowle and Smyth, 2016). Reflecting this, critical (Gallhofer and Haslam, 1997; Gendron, 2018) and social and environmental (Bebbington et al., 2017; Chung and Cho, 2018) strands of accounting research have flourished over the last 25 years and have played important roles in emphasizing the potential social significance of both academic and professional accounting. Among the wide range of social and environmental challenges to which accounting has contributed an understanding (Lai and Stacchezzini, 2021), problems involving inequality are perhaps especially susceptible to the calculative and reporting processes at the heart of accounting practice. It is surprising, therefore, that addressing inequalities has not taken a more prominent place within critical and social and environmental accounting research (Tweedie and Hazleton, 2019). As Tweedie and Hazleton (2019) note, economic inequality is directly relevant to accounting and accountability - both at a societal level, in relation to measuring and calibrating inequality, and at an individual and organizational level in relation to the 
AAAJ 34,6

1314

distribution of profits and disparities in wages. Other research has begun to highlight the relevance to accounting of other forms of inequality - especially gender inequality (Lehman, 2012; Marx, 2019) - and different contexts within which inequality manifests itself, for example, in global SCs (Court et al., 2021).

The COVID-19 pandemic has exposed and intensified substantial and systemic inequalities at various levels, ranging from global and geographic inequalities among developed and developing nations, socio-economic inequalities within societies and inequalities among individuals based on aspects such as age, gender, education and ethnicity (Blundell et al., 2020). The pandemic has thereby not just created new inequalities but has deepened existing underlying inequalities and policy challenges (Blundell et al., 2020; Bambra et al., 2020). Inequality is also embedded in national and international responses to COVID-19, as giving and receiving economic and monetary support and aid (also in the form of vaccine access) is shaped by economic strength as well as the politics of power and influence. These challenges create a pressing need for researchers across disciplines to contribute to debates and solutions about greater equality and the well-being of people in society (Andrew et al., 2021).

In the developed-country context of Australia, Andrew et al. (2021) examine a raft of stimulus measures implemented by the government for both individuals and businesses. The authors are critical of the measures implemented, specifically the measures aimed at providing employment through public infrastructure projects and at providing subsidies to businesses to keep their staff "on the books". Andrew et al. (2021) write that "[w]hile Australian policy responses to the pandemic have included a (temporary) focus on vulnerable people, these same policies have also been recruited to generate cash for businesses and capital to intensify the worth of the wealthy", thus voicing concern that measures to alleviate the impact of the pandemic on vulnerable people might have generated additional benefits for wealthier parts within society. Nikidehaghani and Cortese (2021) voice similar concerns about the implementation of Australia's JobKeeper scheme and highlight its distinct neoliberal characteristics: the intent to keep workers in the workforce, and payments made to employees by the government through the employer. The authors conclude that accounting techniques embedded within the JobKeeper program resulted in a divisive practice; categorizing businesses according to turnover to determine eligibility which in turn resulted in the implementation of strategies that impacted the conduct of businesses and their employees.

Internationally, socio-economic inequalities between and within nations have significantly contributed to the likelihood of contracting COVID-19 and receiving subsequent medical care, with direct impact on mortality rates. The most vulnerable members in society are those who are the least visible, as shown by Christ and Burritt (2021) in their paper on modern slavery in the COVID-19 context. Here, COVID-19 means that victims move even further into vulnerable positions where they are exploited, thus creating substantial challenges for accounting, auditing and accountability to help track and trace victims, especially because capacities for doing so are reduced because of the pandemic.

These papers make important contributions to the many inequalities exposed during the pandemic. We are aware that further research is underway specifically addressing other types of inequalities including gender equality - examining issues such as gendered divisions of labour, gender stereotypes and roles, responses to threat, systemic inequalities in the wake of COVID-19 (Fisher and Ryan, 2021). More generally, this research highlights both the need for and the potential impacts of accounting and accountability research concerned with inequalities. As Andrew et al. (2021) note, "if inequality is created and maintained through discourse and ideology, then accounting has an essential role to play in the production of more equitable futures" (Andrew et al., 2021, p.?). Accountants and accounting, as key stewards and standard-setters in the global economic system, have a vital role to play in 
continuing to expose, measure, understand and repair global inequalities of many kinds, as the research discussed above demonstrates.

\section{Conclusions}

Guest-editing a 175-submission AAAJ special issue was a challenging and at times daunting times of crisis process, but also an exhilarating one that and one which allowed us to appreciate the impressive sense of commitment of the interdisciplinary accounting community and the enormous potential that it can have to make a difference in tackling the big challenges our societies face.

Far from remaining relegated in the (forced) ivory towers of academic life under lockdown, literally hundreds of colleagues decided to engage with the pandemic and its consequences for accounting and accountability, moved by a sense of responsibility and intellectual curiosity to document what was happening around us and contribute to make sense of a phenomenon which has changed the course of history and will probably leave an enduring legacy in our societies, economies and lives. In doing so, they provided a timely and comprehensive picture of the roles played by accounting and accountability at a time when the world was hit by an unprecedented global pandemic.

Along these lines, the 14 papers hosted in this issue provide contingent and contextual accounts of the uses of accounting and the forms of accountability emerging from a diversity of experiences, across countries, organizations and individuals.

At the same time, they also provide very strong messages and lessons for the future, on what accounting and accountability can do in terms of both facilitating and empowering organizations, countries, government and individuals, but also on the constraints and hardships they place on them when facing shocks and exceptional circumstances.

In particular, the studies all appear to point to the need for scholars and practitioners alike to accept that instability and continuous change, and the "routine" nature of exceptional shocks may need to be taken into stronger account when designing, using, exploring and understanding calculative practices, even in the post-COVID-19 era.

They also highlight the importance of values, culture and institutional contexts in shaping accounting and accountability and the need to continue exploring the interplay between them and accounting and accountability systems and the organizational, country and global levels.

Our special issue appears to be a strong reminder of the importance of devoting more attention to the understanding of vulnerabilities, be they financial or non-financial, to people, individuals, organizations or whole countries and to the ways in which calculative practices may support such understanding and actions to address them.

At the same time, the contributions in this special issue show that the pandemic has laid bare existing inequalities and created new ones, highlighting the inherent risks of a narrow view of accounting as a disciplinary tool that may be used to perpetuate inequities, but also its potential to make them more visible and identifiable and thus address and repair them.

The above final reflections show that fruitful future avenues for research remain open for accounting scholars. In shedding new lights on the strengths and weakness, risks and potentials of accounting, accountability and calculative practices under a global pandemic, we hope this special issue will also provide an ideal bridge for us all to collectively make sense of the transition between the pre-COVID-19 and the post-COVID-19 world.

\section{Notes}

1. World Health Organization https://covid19.who.int/ accessed on 7 May 2021

2. For more data on poverty, see World Bank. 2020. Poverty and Shared Prosperity 2020: Reversals of Fortune. Washington, DC: World Bank. doi: 10.1596/978-1-4648-1602-4. License: Creative Commons Attribution CC BY 3.0 IGO 
AAAJ

34,6

1316

\section{References}

Ahmad, S., Connolly, C. and Demirag, I. (2021), "Testing times: governing a pandemic with numbers", Accounting, Auditing and Accountability Journal, Vol. 34 No. 4.

Ahn, P.D. and Wickramasinghe, D. (2021), "Pushing the limits of accountability: big data analytics containing and controlling COVID-19 in South Korea", Accounting, Auditing and Accountability Journal, Vol. 34 No. 4.

Ahrens, T. and Ferry, L. (2021), "Accounting and accountability practices in times of crisis: a Foucauldian perspective on the UK government's response to COVID-19 for England", Accounting, Auditing and Accountability Journal, Vol. 34 No. 4.

Al Mahameed, M., Belal, A., Gebreiter, F. and Lowe, A. (2020), "Social accounting in the context of profound political, social and economic crisis: the case of the Arab Spring", Accounting, Auditing and Accountability Journal. doi: 10.1108/AAAJ-08-2019-4129.

Andrew, J., Baker, M. and Guthrie, J. (2021), "Accounting, inequality and COVID-19 in Australia”, Accounting, Auditing and Accountability Journal, Vol. 34 No. 4.

Bambra, C., Riordan, R., Ford, J. and Matthews, F. (2020), "The COVID-19 pandemic and health inequalities", Journal of Epidemiology and Community Health, Vol. 74 No. 11, pp. 964-968.

Barbera, C., Jones, M., Korac, S., Saliterer, I. and Steccolini, I. (2017), "Governmental financial resilience under austerity in Austria, England and Italy: how do local governments cope with financial shocks?”, Public Administration, Vol. 95 No. 3, pp. 670-697.

Barbera, C., Guarini, E. and Steccolini, I. (2020), "How do governments cope with austerity? The roles of accounting in shaping governmental financial resilience", Accounting, Auditing and Accountability Journal, Vol. 33 No. 3, pp. 529-558.

Bebbington, J. and Unerman, J. (2018), “Achieving the united nations sustainable development goals: an enabling role for accounting research", Accounting, Auditing and Accountability Journal, Vol. 31 No. 1, pp. 2-24.

Bebbington, J., Russell, S. and Thomson, I. (2017), "Accounting and sustainable development: reflections and propositions", Critical Perspectives on Accounting, Vol. 48, pp. 21-34.

Blundell, R., Costa Dias, M., Joyce, R. and Xu, X. (2020), "COVID-19 and inequalities", Fiscal Studies, Vol. 41 No. 2, pp. 291-319.

Boin, A., Stern, E. and Sundelius, B. (2016), The Politics of Crisis Management: Public Leadership under Pressure, Cambridge University Press, Cambridge.

Bracci, E., Humphrey, C., Moll, J. and Steccolini, I. (2015), "Public sector accounting, accountability and austerity: more than balancing the books?", Accounting, Auditing and Accountability Journal, Vol. 28 No. 6, pp. 878-908.

Brammer, S., Branicki, L., Linnenluecke, M. and Smith, T. (2019), "Grand challenges in management research: attributes, achievements, and advancement", Australian Journal of Management, Vol. 44 No. 4, pp. 517-533.

Brammer, S., Branicki, L. and Linnenluecke, M.K. (2020), "COVID-19, societalization, and the future of business in society", Academy of Management Perspectives, Vol. 34 No. 4, pp. 493-507.

Bryer, A.R. (2014), "Conscious practices and purposive action: a qualitative study of accounting and social change”, Critical Perspectives on Accounting, Vol. 25 No. 2, pp. 93-103.

Capelo, M. and Araújo, P. (2019), "Ad hoc accounting and accountability for the local governance of an epidemic crisis: the yellow fever in Cádiz in 1800", De Computis-Revista Española de Historia de la Contabilidad, Vol. 16 No. 2, pp. 42-68.

Carungu, J., Di Pietra, R. and Molinari, M. (2021), "The impact of a humanitarian disaster on the working approach of accountants: a study of contingent effect", Accounting, Auditing and Accountability Journal, Vol. 34 No. 4.

Catchpowle, L. and Smyth, S. (2016), "Accounting and social movements: an exploration of critical accounting praxis", Accounting Forum, Vol. 40 No. 3, pp. 220-234. 
Chabrak, N. and Gendron, Y. (2015), "Promoting research from the 'periphery': engaging critically with the global financial crisis", Critical Perspectives on Accounting, Vol. 30, pp. 1-8.

Chenhall, R.H. (2003), "Management control systems design within its organizational context: findings from contingency-based research and directions for the future", Accounting, Organizations and Society, Vol. 28 Nos 2-3, pp. 127-168.

Christ, K.L. and Burritt, R.L. (2021), "Accounting for modern slavery risk in the time of COVID-19: challenges and opportunities", Accounting, Auditing and Accountability Journal, Vol. 34 No. 4.

Chung, J. and Cho, C.H. (2018), "Current trends within social and environmental accounting research: a literature review”, Accounting Perspectives, Vol. 17 No. 2, pp. 207-239.

Court, C.D., Ferreira, J.P., Hewings, G.J. and Lahr, M.L. (2021), "Accounting for global value chains: rising global inequality in the wake of COVID-19?", International Review of Applied Economics. doi: 10.1080/02692171.2021.1912716.

Delfino, G.F. and van der Kolk, B. (2021), "Remote working, management control changes and employee responses during the COVID-19 crisis", Accounting, Auditing and Accountability Journal, Vol. 34 No. 4.

Demirag, I., Firtin and Tekin, E. (2021), "Managing expectations with emotional accountability: making City hospitals accountable during the COVID-19 pandemic in Turkey", Journal of Budgeting, Accounting and Financial Management, Vol. 32 No. 5, pp. 889-901.

Dumay, J., Guthrie, J. and Rooney, J. (2020), "Being critical about intellectual capital", Critical Perspectives on Accounting, Vol. 70, pp. 1-9.

Fisher, A.N. and Ryan, M.K. (2021), "Gender inequalities during COVID-19", Group Processes and Intergroup Relations, Vol. 24 No. 2, pp. 237-245.

Foucault, M. (1991), "Governmentality", in Burchell, G., Gordon, C. and Miller, P. (Eds), The Foucault Effect: Studies in Governmentality, Hemel Hempstead, Wheatsheaf, pp. 87-104.

Gallhofer, S. and Haslam, J. (1997), "Beyond accounting: the possibilities of accounting and 'critical' accounting research", Critical Perspectives on Accounting, Vol. 8 Nos 1-2, pp. 71-95.

Gendron, Y. (2018), "On the elusive nature of critical (accounting) research", Critical Perspectives on Accounting, Vol. 50, pp. 1-12.

Global Preparedness Monitoring Board (GPMB) (2019), A World at Risk: Annual Report on Global Preparedness for Health Emergencies, World Health Organization, Geneva.

Head, A. (2019), "Forty years of wicked problems literature: forging closer links to policy studies", Policy and Society, Vol. 38, pp. 180-197.

Hodges, R. and Lapsley, I. (2016), "A private sector failure, a public sector crisis - reflections on the Great recession”, Financial Accountability and Management, Vol. 32 No. 3, pp. 265-280.

Huber, C., Gerhardt, N. and Reilley, J. (2021), "Organizing care during the COVID-19 pandemic: the role of accounting in German hospitals", Accounting, Auditing and Accountability Journal, Vol. 34 No. 4.

Jacobs, K. and Cuganesan, S. (2014), "Interdisciplinary accounting research in the public sector: dissolving boundaries to tackle wicked problems", Accounting, Auditing and Accountability Journal, Vol. 27 No. 8, pp. 1250-1256.

Kober, R. and Thamber, P. (2021), "The role of accounting in shaping charities' financial resilience", Accounting, Auditing and Accountability Journal, Vol. 34 No. 4.

Lai, A. and Stacchezzini, R. (2021), "Organisational and professional challenges amid the evolution of sustainability reporting: a theoretical framework and an agenda for future research", Meditari Accountancy Research. doi: 10.1108/medar-02-2021-1199.

Lai, A., Leoni, G. and Stacchezzini, R. (2014), "The socializing effects of accounting in flood recovery", Critical Perspectives on Accounting, Vol. 25 No. 7, pp. 579-603.

Lehman, C. (2012), "We've come a long way! Maybe! Re-imagining gender and accounting", Accounting, Auditing and Accountability Journal, Vol. 25 No. 2, pp. 256-294.
Accounting and management in times of crisis 
AAAJ 34,6

Leider, J.P., DeBruin, D., Reynolds, N., Koch, A. and Seaberg, J. (2017), "Ethical guidance for disaster response, specifically around crisis standards of care: a systematic review", American Journal of Public Health, Vol. 107 No. 9, pp. e1-e9.

Linnenluecke, M.K. (2017), "Resilience in business and management research: a review of influential publications and a research agenda”, International Journal of Management Reviews, Vol. 19 No. 1, pp. 4-30.

Marx, U. (2019), "Accounting for equality: gender budgeting and moderate feminism”, Gender, Work and Organization, Vol. 26 No. 8, pp. 1176-1190.

Matilal, S. and Adhikari, P. (2019), “Accounting in Bhopal: making catastrophe”, Critical Perspectives on Accounting, Vol. 72, pp. 1-24.

Merchant, K.A. and Van der Stede, W.A. (2012), Management Control Systems: Performance Measurement, Evaluation and Incentives, Pearson Education, London.

Mitchell, F., Nørreklit, H., Nørreklit, L., Cinquini, L., Koeppe, F., Magnacca, F., Mauro, S.G., Jakobsen, M., Korhonen, T., Laine, T. and Liboriussen, J.M. (2021), "Evaluating performance management of COVID-19 reality in three European countries: a pragmatic constructivist study", Accounting, Auditing and Accountability Journal, Vol. 34 No. 4.

Murray, C.J., Lopez, A.D., Chin, B., Feehan, D. and Hill, K.H. (2006), "Estimation of potential global pandemic influenza mortality on the basis of vital registry data from the 1918-20 pandemic: a quantitative analysis", The Lancet, Vol. 368 No. 9554, pp. 2211-2218.

Newberry, S. (2020), "Policy conflict: the influence of fiscal targets on reform of New Zealand's natural disaster fund", Financial Accountability and Management, Vol. 36 No. 2, p. 18.

Nikidehaghani, M. and Cortese, C. (2021), "(Job) keeping up appearances”, Accounting, Auditing and Accountability Journal, Vol. 34 No. 4.

Passetti, E., Battaglia, M., Bianchi, L. and Annesi, N. (2021), "Coping with the COVID-19 pandemic: the technical, moral and facilitating role of management control", Accounting, Auditing and Accountability Journal, Vol. 34 No. 4.

Perkiss, S. and Moerman, L. (2017), "Hurricane Katrina: exploring justice and fairness as a sociology of common good (s)", Critical Perspectives on Accounting, Vols 67-68, pp. 1-15.

Rouleau, L., Hällgren, M. and de Rond, M. (2021), "Covid-19 and our understanding of risk, emergencies, and crises”, Journal of Management Studies, 2020 October 25, doi: 10.1111/ joms.12649.

Sargiacomo, M. (2015), "Earthquakes, exceptional government, and extraordinary accounting", Accounting, Organizations and Society, Vol. 42 No. 1, pp. 67-89.

Sargiacomo, M., Ianni, L. and Everett, J. (2014), “Accounting for suffering: calculative practices in the field of disaster relief", Critical Perspectives on Accounting, Vol. 25 No. 7, pp. 652-669.

Sargiacomo, M., Corazza, L., D’Andreamatteo, A., Dumay, J. and Guthrie, J. (2021), "COVID-19 and the governmentality of emergency food in the City of Turin", Accounting, Auditing and Accountability Journal, Vol. 34 No. 4.

Sargiacomo, M. (2014), "Accounting for natural disasters and humanitarian interventions”, Critical Perspectives on Accounting, Vol. 25 No. 7, pp. 576-578.

Sciulli, N. (2018), "Weathering the storm: accountability implications for flood relief and recovery from a local government perspective", Financial Accountability and Management, Vol. 34 No. 1, pp. 30-44.

Steccolini, I. (2019), "Accounting and the post-new public management: re-considering publicness in accounting research", Accounting, Auditing and Accountability Journal, Vol. 32 No. 1, pp. 255-279.

Thomasson, A., Lapsley, I. and Steccolini, I. (2020), "Managing wicked problems: uncovering the roles of budgets, financial systems, and collaboration", Financial Accountability and Management, Vol. 36 No. 2, pp. 113-116. 
Tweedie, D. and Hazelton, J. (2019), "Economic inequality: problems and perspectives for interdisciplinary accounting research”, Accounting, Auditing and Accountability Journal, Vol. 32 No. 7, pp. 1982-2003.

Velayutham, A., Rahman, A.R., Narayan, A. and Wang, M. (2021), "Pandemic turned into pandemonium: the effect on supply chains and the role of accounting information", Accounting, Auditing and Accountability Journal, Vol. 34 No. 4.

Walker, S.P. (2014), "Drought, resettlement and accounting", Critical Perspectives on Accounting, Vol. 25 No. 7, pp. 604-619.

Wilson, D.C., Branicki, L., Sullivan-Taylor, B. and Wilson, A.D. (2010), "Extreme events, organizations and the politics of strategic decision making", Accounting, Auditing and Accountability Journal, Vol. 23 No. 5, pp. 699-721.

\section{Further reading}

Johns Hopkins University and Medicine (2020), "Coronavirus resource centre”, 17 April, available at: https://coronavirus.jhu.edu/map.html (accessed 30 April 2021).

Nanda, S. (2020), "Inequalities and COVID-19", in Ryan, M. (Ed.), COVID-19: Global Pandemic, Societal Responses, Ideological Solutions, Routledge, London, pp. 109-123.

\section{Corresponding author}

Giulia Leoni can be contacted at: giulia.leoni@unige.it

For instructions on how to order reprints of this article, please visit our website:

www.emeraldgrouppublishing.com/licensing/reprints.htm

Or contact us for further details: permissions@emeraldinsight.com 